\title{
Combined treatment of tetrahydrocurcumin and chlorogenic acid exerts potential antihyperglycemic effect on streptozotocin- nicotinamide-induced diabetic rats
}

\author{
Krishnamoorthy Karthikesan, Leelavinothan Pari and Venugopal P. Menon \\ Department of Biochemistry and Biotechnology, Faculty of Science, Annamalai University, Annamalai Nagar - 608002, \\ Tamil Nadu, India; E-mail: paribalaji@gmail.com
}

\begin{abstract}
We have shown that separate dose of tetrahydrocurcumin (THC) at a dose of $80 \mathrm{mg} / \mathrm{kg}$ body weight (b.w.) and chlorogenic acid (CGA) at a dose of $5 \mathrm{mg} / \mathrm{kg}$ b.w. exerts antidiabetic potential in streptozotocin (STZ) $(45 \mathrm{mg} / \mathrm{kg}$ b.w.) nicotinamide induced diabetic rats. In the present study we have attempted to compare the antihyperglycemic activity exerted by the combined treatment of THC/CGA with THC and CGA alone treated diabetic rats. After the experimental period of 45 days we observed that supplementation with combined dose of THC/CGA significantly decreased glycosylated hemoglobin $\left(\mathrm{HbA}_{1 \mathrm{C}}\right)$ and increased the levels of plasma insulin, $\mathrm{C}$-peptide, hemoglobin and glycogen which were decreased upon STZ treatment and also significantly reversed the altered activities of gluconeogenic enzymes such as glucose-6-phosphatase, fructose-1,6-bisphosphatase, and of glycolytic enzymes such as glucokinase and hexokinase in the tissues of experimental rats as compared to their individual supplementation. Thus our results substantiate that though THC and CGA alone found to exert hypoglycemic activity the maximum hypoglycemic effect was always observed in diabetic rats treated THC/CGA and this summed effect seems to have a promising value for the development of a potent phytomedicine for diabetes.
\end{abstract}

Key words: Tetrahydrocurcumin - Chlorogenic acid — Streptozotocin — Insulin — Diabetes

\begin{abstract}
Abbreviations: ANSA, amino naphthol sulphonic acid; ATP, adenosine triphosphate; CGA, chlorogenic acid; DM, diabetes mellitus; G-6-P, glucose-6-phosphate; G-6-Pase, glucose-6-phosphatase; $\mathrm{Hb}$, hemoglobin; $\mathrm{HbA}_{1 \mathrm{C}}$, glycosylated hemoglobin; STZ, streptozotocin; TCA, trichloroacetic acid; THC, tetrahydrocurcumin.
\end{abstract}

\section{Introduction}

Diabetes mellitus (DM) is a group of metabolic disorders characterized by hyperglycemia resulting from defects in insulin secretion, action or both. It has already been established that chronic hyperglycemia affects the normal functioning of eyes, kidneys, nerves, heart and blood vessels (Huang et al. 2005). Impairment in carbohydrate utilization by cells and the abnormal regulation of blood glucose resulting from deficient/defective insulin secretory process

Correspondence to: Leelavinothan Pari, Department of Biochemistry and Biotechnology, Faculty of Science, Annamalai University, Annamalai Nagar - 608 002, Tamil Nadu, India

E-mail: paribalaji@gmail.com are the key pathogenic events in the DM. However, diabetic individuals can control the disease and lower the risk of complications.

Alterations in carbohydrate metabolism in diabetes are frequently accompanied by changes in the activities of the enzymes that control glycolysis and gluconeogenesis in liver and muscle; in such a way the latter process becomes favored (Prince and Kamalakkannan 2006). Alterations in the glucogenic and glucolytic pathways results in increased rate of hepatic glucose production, which lead to the development of overt hyperglycemia, especially fasting hyperglycemia, in patients with type 2 diabetes (DeFronzo et al. 1992). There are several enzymatic checkpoints to control glycolysis (hexokinase, glucokinase), glycogenesis (glycogen synthase kinase-3), glycogenolysis (glycogen phosphorylase) and glu- 
coneogenesis (phosphoenolpyruvate carboxykinase, fructose 1,6-bisphosphatase, glucose-6-phosphatase (G-6-Pase)). The activities of certain enzymes are directly controlled by insulin via phosphorylation and dephosphorylation mechanisms (Zhang et al. 2002).

The oral hypoglycemic drugs used for the management of DM, has severe side effects such as body weight gain, and gastrointestinal disturbances. Therefore, the search for effective and safe treatment regimens is underway. In this context, clinical studies have demonstrated that combinational therapies led to a significantly greater reduction in fasting plasma glucose and glycosylated hemoglobin $\left(\mathrm{HbA}_{1 \mathrm{C}}\right)$ than monotherapy in type 2 diabetes (Marre et al. 2002; Duckworth et al. 2003). Among the metabolites of curcumin, tetrahydrocurcumin (THC) has shown to have increased bioavailability. This metabolite was identified in the cytosol of intestinal and hepatic cells of humans and rats (Naito et al. 2002). The reduction of THC seems to occur primarily in the cytosolic compartment (intestinal or hepatic, possibly via a reductase enzyme) (Ireson 2002). Final reduction of THC to hexahydrocurcuminol may occur in microsomes (possibly by cytochrome $\mathrm{P}_{450}$ reductase) (Ireson 2002). As is stated in previous reports, it possesses various pharmacological properties, which include anti-inflammatory (Nakamura 1998; Hong et al. 2004) anti-amyloidogenic neuroprotection (Ono et al. 2004) and hepatoprotective (Pari and Murugan 2004). We have previously reported that the administration of THC alone produces a significant improvement in the insulin levels and a decrease of blood glucose in streptozotocin (STZ)-nicotinamide-induced diabetic rats (Pari and $\mathrm{Mu}-$ rugan 2005).

Chlorogenic acid (CGA) is a natural phenolic compound found in a variety of foodstuffs, of which coffee is one of the main sources and is consumed by humans worldwide. The daily intake of CGA by coffee drinkers ranges from 0.5 to $1.0 \mathrm{~g} /$ day (Clifford 2000; Olthof et al. 2000). It lowers the blood glucose concentrations and inhibits G-6-Pase, the key enzyme that catalyzes the final step of glycogenolysis and gluconeogenesis, the two main metabolic pathways responsible for the release of glucose from the liver (Hemmerle et al. 1997; Parker et al. 1998; Simon et al. 2000; Herling et al. 2002). Previous experimental data shows that CGA promotes the uptake of glucose by liver cells and regulates the overproduction of glucose by inhibiting G-6-Pase; thereby it controls glycemic status in type 2 diabetes (De Fronzo et al. 1989).

The above findings instigate us to explore the summed effect of THC/CGA on the STZ-induced changes in the levels of glucose, insulin, $\mathrm{Hb}, \mathrm{HbA}_{1 \mathrm{C}}$, hepatic glycogen content, and the activities of carbohydrate metabolizing enzymes and hepatic enzymes in STZ-nicotinamide-induced diabetic rats.

\section{Materials and Methods}

\section{Animals}

Male albino Wistar rats, weighing 180-220 g, bred in the Central Animal House, Rajah Muthiah Medical College, Annamalai University, were obtained and housed in polypropylene cages in a pathogen free environment at an ambient temperature of $28 \pm 2^{\circ} \mathrm{C}$ and $45-55 \%$ relative humidity with $12 \mathrm{~h}$ each of dark and light cycle. Rats were fed pellet diet (Hindustan Lever Ltd., India) and water ad libitum. The animals were maintained in accordance with the guidelines of the National Institute of Nutrition, Indian Council of Medical Research, Hyderabad, India and approved by the Institutional Animal Ethical Committee, Annamalai University (Reg. No. 160/1999/CPCSEA; vide No. 458, 2007).

\section{Drugs and chemicals}

THC (99\% purity: HPLC grade) was a gift sample provided by the Sabinsa Corporation, USA. CGA (99\% purity: HPLC grade) was obtained from Sigma Chemical Co. (St. Louis, MO, USA). STZ (Sigma Aldrich, Germany) and nicotinamide was obtained from Ranbaxy Chemicals Ltd., Mumbai, India. All the other chemicals used in the present study were of analytical grade.

\section{Induction of diabetes}

Non-insulin dependent DM was induced in over night fasted experimental groups by a single intraperitoneal (i.p.) injection of freshly prepared STZ $(45 \mathrm{mg} / \mathrm{kg}$ b.w.) dissolved in $0.1 \mathrm{~mol} / \mathrm{l}$ citrate buffer $(\mathrm{pH} 4.5) 15 \mathrm{~min}$ after the i.p. administration of nicotinamide $(110 \mathrm{mg} / \mathrm{kg}$ b.w.) (Masiello et al. 1998). The animals were allowed to drink $20 \%$ glucose solution overnight to overcome drug-induced hypoglycemia. Control rats were injected with the same volume of isotonic saline. After $72 \mathrm{~h}$, plasma glucose was determined and those rats with fasting glucose levels greater than $250 \mathrm{mg} / \mathrm{dl}$ were served as diabetic rats and used in the present study.

\section{Experimental design}

In this experiment, a total of 30 rats (24 diabetic surviving rats, 6 normal rats) were used. The animals were divided into five groups of six each. Group I: Normal rats. Group II: Diabetic control rats. Group III: Diabetic rats + THC $(80 \mathrm{mg} /$ $\mathrm{kg} /$ day) (Pari and Murugan 2005). Group IV: Diabetic rats + CGA (5 mg/kg/day) (Rodriguez de Sotillo and Hadley 2002). Group V: Diabetic rats + THC $(80 \mathrm{mg} / \mathrm{kg} /$ day $)$ and CGA ( $5 \mathrm{mg} / \mathrm{kg} /$ day). THC and CGA were saturated in water and orally administered to rats using an intragastric tube daily for a period of 45 days. 


\section{Sample collection}

The initial and final body weights of the various groups were recorded. At the end of the experimental period, the animals were fasted overnight, anesthetized using ketamine ( $24 \mathrm{mg} / \mathrm{kg}$ b.w., i.p. injection), and sacrificed by cervical decapitation. Blood samples were collected in tubes containing potassium oxalate and sodium fluoride $(3: 1)$ mixture for the estimation of plasma glucose and insulin. $\mathrm{Hb}$ and $\mathrm{HbA}_{1 \mathrm{C}}$ levels were estimated in whole blood samples. Liver was immediately dissected, washed in ice-cold saline to remove the blood. They were then homogenized in Tris- $\mathrm{HCl}$ buffer $(0.1 \mathrm{~mol} / \mathrm{l}, \mathrm{pH} 7.5)$, centrifuged $(3000 \times g)$ for $10 \mathrm{~min}$, and the supernatant was collected. Biochemical estimations were carried out in the homogenates.

\section{Analytical procedure}

Plasma glucose levels were estimated using a commercial kit (Sigma Diagnostics Pvt. Ltd., Baroda, India) by the method of Trinder (1969). Plasma insulin and C-peptide were assayed by ELISA kit (Boeheringer-Manneheim Kit, Manneheim, Germany).

$\mathrm{Hb}$ was estimated by the cyanmethemoglobin method (Drabkin and Austin 1932). The reaction mixture in a volume of $5.02 \mathrm{ml}$ contained, $5 \mathrm{ml}$ of Drabkin's reagent (this reagent contains $0.05 \mathrm{~g}$ of potassium cyanide, $0.20 \mathrm{~g}$ of potassium ferricyanide and $1 \mathrm{~g}$ of sodium bicarbonate in 1 litre of distilled water ( $\mathrm{pH} 9.6)$ ) and $0.02 \mathrm{ml}$ of blood. The reaction mixture was kept at room temperature for $5 \mathrm{~min}$ to ensure the completion of the reaction and absorbance was read at $540 \mathrm{~nm}$ against a reagent blank.

$\mathrm{HbA}_{1 \mathrm{C}}$ was estimated by the method of Sudhakar Nayak and Pattabiraman (1981) with modifications according to Bannon (1982). To $0.5 \mathrm{ml}$ of packed cell, $5 \mathrm{ml}$ of citrate buffer $(0.1 \mathrm{~mol} / \mathrm{l}, \mathrm{pH} 6.5)$ was added, mixed and incubated at $37^{\circ} \mathrm{C}$ for $15 \mathrm{~min}$, centrifuged and the supernatant was discarded. Then added $0.5 \mathrm{ml}$ of saline mixed and processed for the determination. To an aliquot, $4 \mathrm{ml}$ of $0.1 \mathrm{~mol} / 1$ oxalate in $2 \mathrm{~mol} / \mathrm{l}$ $\mathrm{HCl}$ solution was added, mixed and heated at $100^{\circ} \mathrm{C}$ for $4 \mathrm{~h}$, cooled and precipitated with $2 \mathrm{ml}$ of $40 \%$ trichloroacetic acid (TCA). The mixture was centrifuged, and to an aliquot, $0.05 \mathrm{ml}$ of $80 \%$ phenol and $3 \mathrm{ml}$ of conc. $\mathrm{H}_{2} \mathrm{SO}_{4}$ were added. A set of standards (10-50 mg) was also treated in a similar manner. The colour developed was read at $480 \mathrm{~nm}$ after $30 \mathrm{~min}$.

Hepatic hexokinase was assayed by the method of Brandstrup et al. (1957). The reaction mixture in a total volume of $5.3 \mathrm{ml}$ contained the following solutions: $1 \mathrm{ml}$ of glucose $(0.005 \mathrm{~mol} / \mathrm{l}), 0.5 \mathrm{ml}$ of adenosine triphosphate (ATP) $(0.072$ $\mathrm{mol} / \mathrm{l}), 0.1 \mathrm{ml}$ of magnesium chloride $(0.05 \mathrm{~mol} / \mathrm{l}), 0.4 \mathrm{ml}$ of potassium dihydrogen phosphate $(0.0125 \mathrm{~mol} / \mathrm{l}), 0.4 \mathrm{ml}$ of potassium chloride $(0.1 \mathrm{~mol} / \mathrm{l}), 0.4 \mathrm{ml}$ of sodium fluoride $(0.5$ $\mathrm{mol} / \mathrm{l})$ and $2.5 \mathrm{ml}$ of Tris-HCl buffer $(0.01 \mathrm{~mol} / \mathrm{l}, \mathrm{pH} 8.0)$. The mixture was pre-incubated at $37^{\circ} \mathrm{C}$ for $5 \mathrm{~min}$. The reaction was initiated by the addition of $2 \mathrm{ml}$ of tissue homogenate. $1 \mathrm{ml}$ of the reaction mixture was immediately transferred to the tubes containing $1 \mathrm{ml}$ of $10 \%$ TCA that was considered as zero time. A second aliquot was removed and deproteinised after $30 \mathrm{~min}$ incubation at $37^{\circ} \mathrm{C}$. The protein precipitate was removed by centrifugation and the residual glucose in the supernatant was estimated by the method of Trinder (1969).

G-6-Pase was measured by the method of Koide and Oda (1959). Incubation mixture contained $0.7 \mathrm{ml}$ of citrate buffer (0.1 mol/l, pH 6.5), $0.3 \mathrm{ml}$ of substrate $(0.01 \mathrm{~mol} / \mathrm{l})$ and $0.3 \mathrm{ml}$ of tissue homogenate. The reaction mixture was incubated at $37^{\circ} \mathrm{C}$ for $1 \mathrm{~h}$. Addition of $1 \mathrm{ml}$ of $10 \%$ TCA to the reaction tubes terminated the reaction of the enzyme. The suspension was centrifuged and the phosphorus content of the supernatant was estimated by the method of Fiske and Subbarow (1925). The supernatant was made up to known volume. To this $1 \mathrm{ml}$ of ammonium molybdate was added followed by $0.4 \mathrm{ml}$ of amino naphthol sulphonic acid (ANSA). The blue colour developed after $20 \mathrm{~min}$ was read at $680 \mathrm{~nm}$.

Fructose-1,6-bisphosphatase activity was measured by Gancedo and Gancedo (1971). The assay mixture in a final volume of $2 \mathrm{ml}$ contained $1.2 \mathrm{ml}$ of Tris- $\mathrm{HCl}$ buffer $(0.1 \mathrm{~mol} / \mathrm{l}$, $\mathrm{pH} 7.0), 0.1 \mathrm{ml}$ of substrate $(0.05 \mathrm{~mol} / \mathrm{l}), 0.25 \mathrm{ml}$ of magnesium chloride $(0.1 \mathrm{~mol} / \mathrm{l}), 0.1 \mathrm{ml}$ of potassium chloride solution $(0.1$ $\mathrm{mol} / \mathrm{l}), 0.25 \mathrm{ml}$ of ethylene diamine tetra acetic acid (EDTA) $(0.001 \mathrm{~mol} / \mathrm{l})$ solution and $0.1 \mathrm{ml}$ of enzyme homogenate. The incubation was carried out at $37^{\circ} \mathrm{C}$ for $5 \mathrm{~min}$. The reaction was terminated by the addition of $10 \%$ TCA. The suspension was centrifuged and the supernatant was used for phosphorus estimation by the method of Fiske and Subbarow (1925). The supernatant was made up to known volume. To this $1 \mathrm{ml}$ of ammonium molybdate was added followed by $0.4 \mathrm{ml}$ of ANSA. The blue colour developed after $20 \mathrm{~min}$ was read at $680 \mathrm{~nm}$.

Liver and muscle glycogen were estimated by the method of Morales et al. (1973). The alkali extract of the tissue was prepared by digesting $50 \mathrm{mg}$ of fresh tissue with $3 \mathrm{ml}$ of $30 \%$ potassium hydroxide solution in boiling water bath for $15 \mathrm{~min}$. The tubes were cooled and mixed with $5 \mathrm{ml}$ of absolute alcohol and a drop of $1 \mathrm{~mol} / \mathrm{l}$ ammonium acetate were added to precipitate glycogen and left in the freezer overnight for complete precipitation. Glycogen was collected by centrifugation at $2000 \times g$ for $20 \mathrm{~min}$. The precipitate was dissolved in distilled water with the aid of heating and again the glycogen was re-precipitated with alcohol and $1 \mathrm{~mol} / \mathrm{l}$ ammonium acetate and centrifuged. The final precipitate was dissolved in saturated ammonium chloride solution and $4 \mathrm{ml}$ of anthrone reagent was added by cooling the tubes in an ice bath. The tubes were shaken well, covered with marble caps and heated in a boiling water bath for $20 \mathrm{~min}$. After cooling, the absorbance was read at $640 \mathrm{~nm}$ against reagent blank treated in a similar manner. Standard glucose $(1 \mathrm{mg} / \mathrm{ml})$ solution was also treated similarly. 


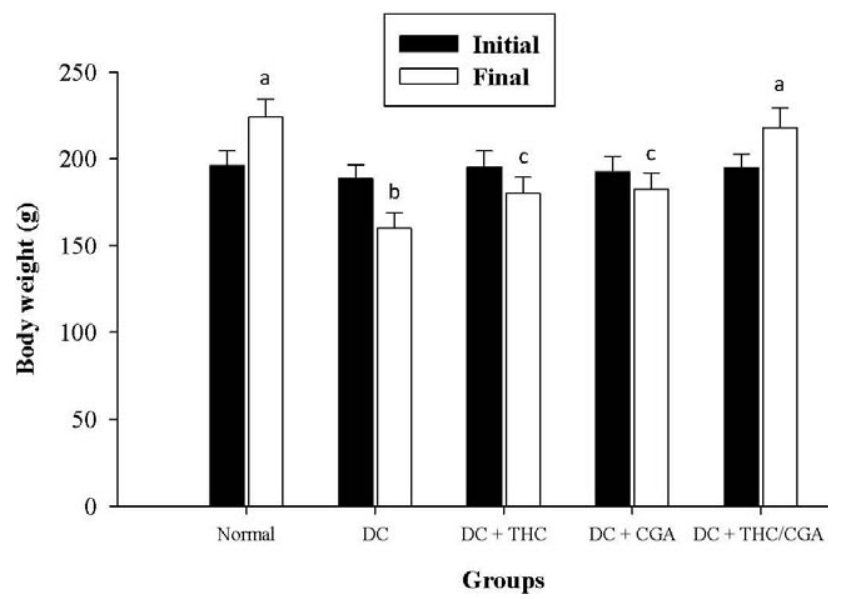

Figure 1. Changes in the body weight of normal and experimental rats. DC, diabetic control; DC + THC $(80 \mathrm{mg} / \mathrm{kg})$; DC + CGA $(5 \mathrm{mg} / \mathrm{kg}) ; \mathrm{DC}+\mathrm{THC} / \mathrm{CGA}(80 / 5 \mathrm{mg} / \mathrm{kg})$. Values that have a different superscript letter $(\mathrm{a}, \mathrm{b}$ and $\mathrm{c}$ ) differ significantly with each other $(p<0.05$, DMRT).

\section{Statistical analysis}

All the data were expressed as mean \pm S.D. for six rats in each group $(n=6)$. The statistical significance was evaluated by one-way analysis of variance (ANOVA) using SPSS version 15 (SPSS, Cary, NC, USA) and the individual comparisons were obtained by Duncan's multiple range test (DMRT). Values were considered statistically significant when $p<0.05$ (Duncan 1957).

\section{Results}

\section{Body weight}

Figure 1 illustrates the changes in the body weight of normal and experimental animals. During the experimental period, there was a significant $(p<0.05)$ decrease in the body weight of diabetic control rats compared with that of normal rats. Diabetic rats treated with THC/CGA showed a significant $(p<0.05)$ increase in body weight when compared with diabetic control rats. However, there is no significant $(p<0.05)$ change in body weight in rats treated with the combined dosage of THC and CGA as compared to normal rats.

\section{Measurement of plasma glucose}

Table 1 shows the levels of plasma glucose in normal and experimental rats. In diabetic control rats, there was a significant $(p<0.05)$ increase in the levels of plasma glucose when compared to normal rats. The combined oral dose of THC/CGA to diabetic rats significantly $(p<0.05)$ decreased plasma glucose when compared with diabetic control rats.

\section{Estimation of plasma insulin and C-peptide}

Table 1 depicts the levels of insulin and C-peptide in normal and experimental rats. In diabetic control rats, there was a significant $(p<0.05)$ decrease in the levels of insulin and $\mathrm{C}$-peptide when compared to normal rats. The combined administration of THC/CGA to the diabetic rats significantly $(p<0.05)$ increased the levels of plasma insulin and C-peptide when compared with diabetic control rats.

\section{Determination of $\mathrm{Hb}$ and $\mathrm{HbA}_{1 \mathrm{C}}$}

Table 1 shows the levels of $\mathrm{Hb}$ and $\mathrm{HbA}_{1 \mathrm{C}}$ in normal and experimental rats. In diabetic control rats, there was a significant $(p<0.05)$ increase in the levels of $\mathrm{HbA}_{1 \mathrm{C}}$ and a decrease in $\mathrm{Hb}$ when compared to normal rats. On oral dosage of THC/CGA to diabetic rats significantly $(p<0.05)$ increased the $\mathrm{Hb}$ and decreased the $\mathrm{HbA}_{1 \mathrm{C}}$ when compared with diabetic control rats.

\section{Activities of gluconeogenic enzymes}

Table 2 depicts the activities of carbohydrate metabolizing enzymes in liver of normal, diabetic and THC/CGA-treated diabetic rats. The activities of gluconeogenic enzymes: G6-Pase and fructose-1,6-bisphosphatase were significantly

Table 1. Effect of THC and CGA in the levels of $\mathrm{Hb}, \mathrm{HbA}_{1 \mathrm{C}}$, plasma glucose, insulin and C-peptide in normal and experimental rats

\begin{tabular}{|c|c|c|c|c|c|}
\hline Groups & Normal & Diabetic control & $\begin{array}{l}\text { Diabetic + THC } \\
\quad(80 \mathrm{mg} / \mathrm{kg})\end{array}$ & $\begin{array}{l}\text { Diabetic + CGA } \\
(5 \mathrm{mg} / \mathrm{kg})\end{array}$ & $\begin{array}{c}\text { Diabetic + THC/ } \\
\text { CGA }(80 / 5 \mathrm{mg} / \mathrm{kg})\end{array}$ \\
\hline $\mathrm{Hb}(\mathrm{g} / \mathrm{dl})$ & $12.07 \pm 0.99^{\mathrm{a}}$ & $9.22 \pm 0.64^{b}$ & $11.02 \pm 0.46^{\mathrm{c}}$ & $10.82 \pm 0.84^{\mathrm{c}}$ & $12.12 \pm 0.99^{\mathrm{a}}$ \\
\hline $\mathrm{HbA}_{1 \mathrm{C}}(\mathrm{mg} / \mathrm{g} \mathrm{Hb})$ & $0.25 \pm 0.02^{\mathrm{a}}$ & $0.68 \pm 0.05^{\mathrm{b}}$ & $0.36 \pm 0.03^{\mathrm{c}}$ & $0.40 \pm 0.04^{\mathrm{d}}$ & $0.29 \pm 0.02^{\mathrm{a}}$ \\
\hline Plasma glucose (mg/dl) & $93.42 \pm 7.58^{\mathrm{a}}$ & $282.28 \pm 8.87^{\mathrm{b}}$ & $108.04 \pm 7.12^{\mathrm{c}}$ & $105.02 \pm 6.96^{\mathrm{c}}$ & $95.24 \pm 6.82^{\mathrm{a}}$ \\
\hline Insulin $(\mu \mathrm{U} / \mathrm{ml})$ & $12.98 \pm 0.99^{\mathrm{a}}$ & $3.86 \pm 0.04^{\mathrm{b}}$ & $9.27 \pm 0.42^{\mathrm{c}}$ & $9.35 \pm 0.50^{\mathrm{c}}$ & $12.56 \pm 1.54^{\mathrm{a}}$ \\
\hline C-peptide (ng/ml) & $22.49 \pm 1.629^{\mathrm{a}}$ & $12.08 \pm 1.31^{b}$ & $17.46 \pm 1.62^{\mathrm{c}}$ & $18.82 \pm 1.77^{\mathrm{c}}$ & $21.98 \pm 1.79^{\mathrm{a}}$ \\
\hline
\end{tabular}

Values that have a different superscript letter (a,b,c and d) differ significantly with each other $(p<0.05, \mathrm{DMRT})$. 
Table 2. Changes in the activities of G-6-Pase, fructose-1,6-bisphosphatase, hexokinase and glucokinase, and in the levels of tissue glycogen in normal and experimental rats

\begin{tabular}{|c|c|c|c|c|c|}
\hline Groups & Normal & Diabetic control & $\begin{array}{l}\text { Diabetic + THC } \\
\quad(80 \mathrm{mg} / \mathrm{kg})\end{array}$ & $\begin{array}{l}\text { Diabetic + CGA } \\
\quad(5 \mathrm{mg} / \mathrm{kg})\end{array}$ & $\begin{array}{c}\text { Diabetic }+ \\
\text { THC/CGA }(80 / 5 \\
\mathrm{mg} / \mathrm{kg}) \\
\end{array}$ \\
\hline \multicolumn{6}{|l|}{ Gluconeogenic enzymes } \\
\hline $\begin{array}{l}\text { Glucose-6-phosphatase } \\
\text { ( } \mu \mathrm{mol} \text { of } \mathrm{Pi} \text { liberated } / \mathrm{min} / \mathrm{mg} \text { protein) }\end{array}$ & $0.18 \pm 0.01^{\mathrm{a}}$ & $0.28 \pm 0.02^{b}$ & $0.21 \pm 0.02^{\mathrm{c}}$ & $0.22 \pm 0.02^{\mathrm{c}}$ & $0.19 \pm 0.01^{\mathrm{a}}$ \\
\hline $\begin{array}{l}\text { Fructose-1, 6-bisphosphatase } \\
\text { ( } \mu \mathrm{mol} \text { of Pi liberated/h/mg protein) }\end{array}$ & $0.36 \pm 0.03^{\mathrm{a}}$ & $0.58 \pm 0.04^{\mathrm{b}}$ & $0.42 \pm 0.03^{c}$ & $0.41 \pm 0.03^{\mathrm{c}}$ & $0.35 \pm 0.03^{\mathrm{a}}$ \\
\hline
\end{tabular}

\begin{tabular}{lrrrrr}
\hline Glycolytic enzymes & & & & \\
Hexokinase \\
$\begin{array}{l}\mu \text { mol of glucose phosphorylated/min/g } \\
\text { protein) }\end{array}$ & $150.24 \pm 11.60^{\mathrm{a}}$ & $108.42 \pm 8.51^{\mathrm{b}}$ & $136.42 \pm 5.37^{\mathrm{c}}$ & $139.48 \pm 6.05^{\mathrm{c}}$ & $151.88 \pm 12.05^{\mathrm{a}}$ \\
$\begin{array}{l}\text { Glucokinase }(\mathrm{U} / \mathrm{h} / \mathrm{mg} \text { protein) } \\
\text { Glycogen in liver }(\mathrm{mg} / \mathrm{g} \text { tissue) }\end{array}$ & $0.30 \pm 0.02^{\mathrm{a}}$ & $0.09 \pm 0.01^{\mathrm{b}}$ & $0.25 \pm 0.02^{\mathrm{c}}$ & $0.26 \pm 0.02^{\mathrm{c}}$ & $0.29 \pm 0.02^{\mathrm{a}}$ \\
\hline Glycogen in muscle $(\mathrm{mg} / \mathrm{g}$ tissue) & $34.05 \pm 2.59^{\mathrm{a}}$ & $19.98 \pm 1.46^{\mathrm{b}}$ & $28.78 \pm 2.37^{\mathrm{c}}$ & $29.36 \pm 2.29^{\mathrm{c}}$ & $33.12 \pm 2.47^{\mathrm{a}}$ \\
\hline
\end{tabular}

Values that have a different superscript letter $(a, b, c)$ differ significantly with each other $(p<0.05$, DMRT).

$(p<0.05)$ increased in diabetic control rats. The administration of THC/CGA to diabetic rats significantly $(p<0.05)$ brought back their activities to normal levels.

\section{Activities of glycolytic enzymes}

The activities of glycolytic enzymes (hexokinase and glucokinase) were found to be significantly $(p<0.05) \mathrm{de}$ creased in diabetic control rats when compared to normal rats. Intragastric administration of THC/CGA to diabetic rats significantly $(p<0.05)$ restored the activities of above enzymes to normal (Table 2).

\section{Determination of glycogen}

Table 2 shows that glycogen content is significantly $(p<0.05)$ decreased in both liver and muscles of diabetic control rats as when compared to normal rats. Treatment with THC/CGA to diabetic rats significantly $(p<0.05)$ reversed the above changes to normal.

\section{Discussion}

DM was induced by STZ-nicotinamide, which brings destruction of $\beta$-cells of the islets of Langerhans in the pancreas (Kavalali 2002). Over-production (excessive hepatic glycogenolysis and gluconeogenesis) and decreased utilization of glucose by the tissues are the fundamental basis of hyperglycemia in DM (Latner 1958). In addition, loss of body weight may be due to excessive breakdown of tissue proteins during diabetes (Chatterjee and Shinde 2002).
In the present study, THC exhibited a glucose lowering action by stimulating the pancreatic $\beta$-cells to release more insulin in diabetic rats (Pari and Murugan 2005). CGA is a novel insulin sensitizer that potentiates insulin action similar to the therapeutic action of metformin (McCarty 2005). On the other hand, CGA reduces blood glucose level by virtue of directly inhibiting G-6-Pase activity, with the related effects of hepatic glycogenolysis (Parker et al. 1998) and gluconeogenesis (Van Dijk 2001). On the combined dosage THC/CGA extensively normalized the blood glucose and increased plasma insulin concentrations when compared with their individual effects.

C-peptide and insulin are produced in equimolar amounts by the $\beta$-cells of islets of Langerhans in the pancreas and released into circulation (Wahren et al. 2001). An increase in C-peptide levels in diabetic rats treated with THC/CGA correlates well with the increased insulin secretion (endogenous secretion) thereby confirming the partial regenerating $\beta$-cells of the islets of Langerhans (data not shown).

Insulin has an anabolic effect on protein metabolism (Murray 2000), which may be responsible for the increased level of $\mathrm{Hb}$ in THC/CGA. In uncontrolled or poorly controlled diabetes, there is an increased glycosylation of a number of proteins, including $\mathrm{Hb}$ (Alberti and Press 1982). $\mathrm{HbA}_{1 \mathrm{C}}$ was drastically increased in induced diabetic rats, and this increase is directly proportional to fasting blood glucose levels (Koeing et al. 1976). In the present study, the combined treatment of THC/CGA to diabetic rat brought $\mathrm{Hb}$ and $\mathrm{HbA}_{1 \mathrm{C}}$ to near normal levels, as a result of improvement in glycemic status.

Glycogen is the primary intracellular storable form of glucose and its level in various tissues especially in liver and 
skeletal muscles indicates direct reflection of insulin activity since it regulates glycogen storage by stimulating glycogen synthase and inhibiting glycogen phosphorylase (Golden et al. 1979). Because STZ causes destruction of $\beta$-cells of islets of Langerhans resulting in marked decrease in insulin levels, the glycogen content in tissues (liver and muscle) decrease as the invasion of glucose in the liver is inhibited in the absence of insulin (Weber et al. 1966; Vats et al. 2004). Our results showed that on administration with THC/CGA to diabetic rats significantly elevated both muscle and hepatic glycogen content, which could be due to increased insulin levels.

Liver plays a pivotal role in glycolysis and gluconeogenesis. The decreased activities of hexokinase, glucokinase and phosphofructokinase, is due to (partial or total) deficiency of insulin and derangements of carbohydrate metabolism, which impairs the glucose utilization and augmented the hepatic glucose production (Hikino and Mizuno 1989). In our study, the activities of glycolytic enzymes (hexokinase and glucokinase) were decreased in the liver of diabetic rats, which may be due to deficiency of insulin. The combined administration of THC/CGA to diabetic rats leads to the increased levels of insulin, which, in turn, activates the respective enzymes, thereby increases the utilization of glucose by the liver.

Changes in glucose metabolism in diabetes are frequently accompanied by changes in the activities of the enzymes that control glycolysis and gluconeogenesis in liver and muscle, such that the latter process becomes favored (Prince and Kamalakkannan 2006). One of the key enzymes in the catabolism of glucose is hexokinase (Ugochukwu and Babady 2003; Ashokkumar and Pari 2005), which phosphorylates glucose by transferring a phosphoryl group from ATP, to form glucose-6-phosphate (G-6-P) (Pari and Amarnath Satheesh 2004).

G-6-Pase, an integral protein of the endoplasmic reticulum, is involved in gluconeogenesis and glycogenolysis where it catalyzes the hydrolysis of G-6-P to glucose and phosphate. Glucose is transported out of the liver to increase blood glucose concentration. In DM, the activities of G-6-Pase and fructose-1,6-bisphosphatase are decreased because of defects in insulin secretion/action (Chen et al. 2000; Wiernsperger and Bailey 1999). However, the administration of THC/CGA to diabetic rats reversed the activities of the above enzymes and decreases gluconeogenesis.

Phenolic compounds with hydroxyl group were shown to exert antioxidant activity by scavenging free radicals. THC possesses phenolic hydroxyl and $\beta$-diketone group that exhibits antioxidant and antidiabetic properties (Sugiyama et al. 1996; Murugan and Pari 2006). Similarly CGA also possess six different $-\mathrm{OH}$ groups and a $-\mathrm{COOH}$ group renders it to behave as an antidiabetic agent (Saremi et al. 2003; Zang et al. 2003). These findings elucidate the structural activity relationships of THC and CGA separately. Since combinational therapies are more beneficial than individual therapies the above two antidiabetic principles are studied for their efficacy since their structural conformations exhibits antidiabetic activities. The daily administration of THC/CGA to diabetic rats shows pronounced protective effects as it shows statistically significant increase in the body weight when compared with diabetic control rats. This could be the result of improved glycemic control. Findings of the present study reveal that hypoglycemic activity was more pronounced in combined treatment (THC/CGA) rather than individual treatment of THC and CGA. The multiple functional groups found in THC and CGA, which might be the underlying factor for their summed effect to act as potential antidiabetic agents. Further mechanistic studies are essential to formulate THC/CGA as potential antihyperglycemic agent.

Acknowledgement. The authors wish to thank the University Grants Commission, New Delhi Project No. F. No. 32-605/2006 (SR) for the research grant and a research fellowship to $\mathrm{Mr}$. K. Karthikesan.

\section{References}

Alberti K. G. M. M., Press C. M. (1982): The biochemistry and the complications of diabetes. J. Complicat. Diabetes 43, 231-270

Ashokkumar N., Pari L. (2005): Effect of N-benzoyl-D-phenylalanine and metformin on carbohydrate metabolic enzymes in neonatal streptozotocin diabetic rats. Clin. Chim. Acta 35, 1105-1113

Bannon P. (1982): Effect of $\mathrm{pH}$ on the elimination of the labile fraction of glycosylated hemoglobin. Clin. Chem. 28, 2183

Brandstrup N., Kirk J. E., Bruni C. (1957): The hexokinase and phosphoglucoisomerase activities of aortic and pulmonary artery tissue in individuals of various ages. J. Gerontol. 12, 166-171

Chatterjee M. N., Shinde R. (2002): Textbook of Medical Biochemistry. (Eds. Jaypee Brothers), Medical Publishers Ltd, pp 317, New Delhi

Chen R., Meseck M., McEvoy R. C., Woo S. L. (2000): Glucosestimulated and self-limiting insulin production by glucose 6-phosphatase promoter driven insulin expression in hepatoma cells. Gene Ther. 7, 1802-1809; doi:10.1038/ sj.gt. 3301306

Clifford M. N. (2000): Chlorogenic acids and other cinnamates-nature, occurrence, dietary burden, absorption and metabolism. J. Sci. Food Agr. 80, 1033-1043; doi:10.1002/(SICI)1097-0010(20000515)80:7<1033:: AID-JSFA595>3.0.CO;2-T

De Fronzo R. A., Ferrannini E., Simonson D. C. (1989): Fasting hyperglycemia in non-insulin-dependent diabetes mellitus: contributions of excessive hepatic glucose production and impaired tissue glucose uptake. Metabolism 38, 387-395; doi:10.1016/0026-0495(89)90129-7 
DeFronzo R. A., Bonadonna R. C., Ferrannini E. (1992): Pathogenesis of NIDDM. A balanced overview. Diabetes Care 15, 318-368; doi:10.2337/diacare.15.3.318

Drabkin D. L., Austin J. M. (1932): Spectrophotometric constants for common haemoglobin derivatives in human, dog and rabbit blood. J. Biol. Chem. 98, 719-733

Duckworth W., Marcelli M., Padden M., Kellick K., Duhancik T., Wilhardt M., Colgan K., Romie A. (2003): Improvements in glycemic control in type 2 diabetes patients switched from sulfonylurea co-administered with metformin to glyburide-metformin tablets. J. Manage. Care Pharm. 9, 256-262

Duncan B. D. (1957): Multiple range tests for correlated and heteroscedastic means. Biometrics 13, 359-364; doi: $10.2307 / 2527799$

Fiske C. H., Subbarow J. (1925): The colorimetric determination of phosphorous. J. Biol. Chem. 66, 375-400

Gancedo J. M., Gancedo C. (1971): Fructose-1,6-diphosphatase, phospho-fructokinase and glucose-6-phosphate dehydrogenase from fermenting and non fermenting yeasts. Arch. Microbiol. 76, 132-138; doi:10.1007/BF00411787

Golden S., Wals P. A., Okajima F., Katz J. (1979): Glycogen synthesis by hepatocytes from diabetic rats. Biochem. J. $182,727-734$

Hemmerle H., Burger H. J., Below P., Schubert G., Rippel R., Schindler P. W., Paulus, E., Herling A. W. (1997): Chlorogenic acid and synthetic chlorogenic acid derivatives: novel inhibitors of hepatic glucose-6-phosphatase translocase. J. Med. Chem. 40, 137-145; doi:10.1021/jm9607360

Herling A. W., Schwab D., Burger H. J., Maas J., Hammerl R., Schmidt D., Strohschein S., Hemmerle H., Schubert G., Petry S., Kramer W. (2002): Prolonged blood glucose reduction in mrp-2 deficient rats (GY/TR (-)) by the glucose-6-phosphate translocase inhibitor S 3025. Biochem. Biophys. Acta 1569, 105-110

Hikino H., Mizuno T. (1989): Hypoglycemic actions of some heteroglycans of Ganoderma lucidum fruit bodies. Planta Med. 55, 385; doi:10.1055/s-2006-962033

Hong J., Bose M., Ju J., Ryu J. H., Chen X., Sang S., Lee M. J., Yang C. S. (2004): Modulation of arachidonic acid metabolism by curcumin and related $\beta$ - diketone derivatives: effects on cytosolic phospholipase A(2), cyclooxygenases and 5lipoxygenase. Carcinogenesis 25, 1671-1679; doi:10.1093/ carcin/bgh 165

Huang T. H. W., Peng G., Kota B. P., Li G. Q., Yamahara J., Roufogalis B. D., Li. Y. (2005): Anti-diabetic action of Punica granatum flower extract: activation of PPAR-c and identification of an active component. Toxicol. Appl. Pharm. 207, 160-169; doi:10.1016/j.taap.2004.12.009

Ireson C. R. (2002): Metabolism of the cancer chemopreventive agent curcumin in human and rat intestine. Cancer. Epidem. Biomar. 11, 105-111

Kavalali E. T. (2002): SNARE interactions in membrane trafficking: a perspective from ammalian central synapses. Bioessays 249, 26-36

Koeing R. J., Peterson C. M., Jones R. L., Saudek C., Lehman M., Cerami A. (1976): Correlation of glucose regulation and haemoglobin A1c in diabetes mellitus. New Engl. J. Med. 295, 417-420
Koide H., Oda T. (1959): Pathological occurrence of glucose-6phosphatase in serum in liver diseases. Clin. Chim. Acta 4, 554-561; doi:10.1016/0009-8981(59)90165-2

Latner A. L. (1958): Intrinsic factor and vitamin B12 absorption. Brit. Med. J. 2, 278-281; doi:10.1136/bmj.2.5091.278

Marre M., Howlett H., Lehert P., Allavoine T. (2002). Improved glycaemic control with metformin-glibenclamide combined tablet therapy (Glucovance) in type 2 diabetic patients inadequately controlled on metformin. Diabetic Med. 19, 673-680; doi:10.1046/j.1464-5491.2002.00774.x

Masiello P., Broca C., Gross R., Roye M., Manteghetti M., HillaireBuys D., Novelli M., Ibes G. (1998): Experimental NIDDM: development of a new model in adult rats administered streptozotocin and nicotinamide. Diabetes 47, 224-229; doi:10.2337/diabetes.47.2.224

McCarty M. F. (2005): A chlorogenic acid-induced increase in GLP-1 production may mediate the impact of heavy coffee consumption on diabetes risk. Med. Hypotheses 64, 848-853; doi:10.1016/j.mehy.2004.03.037

Morales M. A., Jabbagy A. J., Tenenzi H. P. (1973): Mutations affecting accumulation of glycogen. Neurospora N. Lett. 20, 24-25

Murugan P., Pari L. (2006): Antioxidant effect of tetrahydrocurcumin in streptozotocin - nicotinamide induced diabetic rats. Life Sci. 79, 1720-1728; doi:10.1016/ j.lfs.2006.06.001

Murray R. K., Granner D. K., Mayes P. A., Rodwell V. W. (2000): Harper Biochemistry. (Eds. Appleton and Lange) Stanford, Connecticut

Naito M., Wu X., Normura H., Kodama M., Kato Y., Osaswa T. (2002): The protective effect of tetrahydrocurcumin on oxidative stress in cholesterol-fed rabbits. J. Atheroscler. Thromb. 9, 243-250

Nakamura Y. (1998): Inhibitory effect and tetrahydrocurcuminoids on the tumor promoter induced reactive oxygen species generation in leucocyte, in vitro and in vivo. Jpn. J. Cancer Res. 89, 361-370

Olthof M. R., Hollman P. C. H., Katan M. B. (2000): Chlorogenic acid and caffeic acid are absorbed in humans. J. Nutr. 131, 66-71

Ono K., Hasegawa K., Naiki H., Yamada M. (2004): Curcumin has potent anti-amyloidogenic effects for Alzheimer's beta-amyloid fibrils in vitro. J. Neurosci. 75, 742-750; doi:10.1002/jnr.20025

Pari L., Amarnath Satheesh M. (2004): Antidiabetic activity of Boerhaavia diffusa L. effect on hepatic key enzymes in experimental diabetes. J. Ethnopharmacol. 91, 109-113; doi:10.1016/j.jep.2003.12.013

Pari L., Murugan P. (2004): Protective role of tetrahydrocurcumin against erythromycin estolate induced hepatotoxicity. Pharm. Res. 49, 481-486; doi:10.1016/ j.phrs.2003.11.005

Pari L., Murugan P. (2005): Effect of tetrahydrocurcumin on blood glucose, plasma insulin and hepatic key enzymes in streptozotocin induced diabetic rats. J. Basic. Clin. Physiol. Pharmacol. 16, 257-274

Parker J. C., Vanvolkenburg M. A., Levy C. B., Martin W. H., Burk S. H., Kwon Y., Giragossian C., Gant T. G., Carpino P. A., McPherson R. K., Vestergaard P., Treadway J. L. (1998): 
Plasma glucose levels are reduced in rats and mice treated with an inhibitor of glucose-6-phosphate translocase. Diabetes 47, 1630-1636; doi:10.2337/diabetes.47.10.1630

Prince S. M., Kamalakkannan N. (2006): Rutin improves glucose homeostasis in streptozotocin diabetic tissues by altering glycolytic and gluconeogenic enzymes. J. Biochem. Mol. Toxic. 20, 96-102; doi:10.1002/jbt.20117

Rodriguez de Sotillo D. V., Hadley M. (2002): Chlorogenic acid modifies plasma and liver concentrations of: cholesterol, triacylglycerol, and minerals in (fa/fa) Zucker rats. J. Nutr. Biochem. 13, 717-726; doi:10.1016/S09552863(02)00231-0

Saremi A., Tulloch-Reid M., Knowler W. C. (2003): Coffee consumption and the incidence of type 2 diabetes. Diabetes Care 26, 2211e2

Simon C., Herling A. W., Preibish G., Burger H. J. (2000): Upregulation of hepatic glucose 6-phosphatase gene expression in rats treated with an inhibitor of glucose-6-phosphate translocase. Arch. Biochem. Biophys. 373, 418-428; doi:10.1006/abbi.1999.1560

Sudhakar Nayak S., Pattabiraman T. N. (1981): A new colorimetric method for the estimation of glycosylated hemoglobin. Clin. Chim. Acta. 109, 267-274; doi:10.1016/00098981(81)90312-0

Sugiyama Y., Kawakishi S., Osawa T. (1996): Involvement of the $\beta$-diketone moiety in the antioxidant mechanism of tetrahydrocurcuminoids. Biochem. Pharmacol. 52, 519-525; doi:10.1016/0006-2952(96)00302-4

Trinder P. (1969): Determination of glucose in blood using glucose oxidase with an alternative oxygen acceptor. Ann. Clin. Biochem. 6, 24

Ugochukwu N. H., Babady N. E. (2003): Antihyperglycemic effect of aqueous and ethanolic extracts of Gongronema latifolium leaves on glucose and glycogen metabolism in livers of normal and streptozotocin-induced diabetic rats. Life Sci. 73, 1925-1938; doi:10.1016/S0024-3205(03)00543-5
Van Dijk T. H., Van Der Sluijs F. H., Wiegman C. H., Baller J. F. W., Gustafson L. A., Burger H. J., Herling A. W., Kuipers F., Meijer A. J., Reijngoud D. J. (2001): Acute inhibition of hepatic glucose-6-phosphatase does not affect gluconeogenesis but directs gluconeogenic flux toward glycogen in fasted rats. J. Biol. Chem. 276, 25727-25735; doi:10.1074/jbc.M101223200

Vats V., Yadav S. P., Grover J. K. (2004): Ethanolic extract of Ocimum sanctum leaves partially attenuates streptozotocin-induced alterations in glycogen content and carbohydrate metabolism in rats. J. Ethnopharmacol. 90, 155-160; doi:10.1016/j.jep.2003.09.034

Wahren J., Ekberg K., Samnegard B., Johansson B. L. (2001): Cpeptide: a new potential in the treatment of diabetic nephropathy. Current Diabetic Reports 1, 261-266; doi:10.1007/s11892-001-0044-4

Weber G., Lea M. A., Fisher E. A. (1966): Regulatory pattern of liver carbohydrate metabolizing enzymes; insulin as an inducer of key glycolytic enzymes. Enzymol. Biol. Clin. 7, 11-24

Wiernsperger N. F., Bailey C. J. (1999): The antihyperglycaemic effect of metformin: therapeutic and cellular mechanisms. Drug 58, 31-39; doi:10.2165/00003495-199958001-00009

Zang L. Y., Cosma G., Gardner H., Castranova V., Vallyathan V. (2003): Effect of chlorogenic acid on hydroxyl radical. Mol. Cell. Biochem. 247, 205-210; doi:10.1023/ A:1024103428348

Zhang B., Xiang H. D., Mao W. B., Guo X. H., Wang J. C., Jia W. P., Yu M., Li Q. F., Fu Z. Y., Cao W. H., Qian R. L. (2002): Epidemiological survey of chronic vascular complications of type 2 diabetic in-patients in four municipalities. Zhongguo Yi Xue Ke Xue Yuan Xue Bao 24, 452-456 (in Chinese)

Received: June 1, 2009

Final version accepted: September 1, 2009 